\title{
OLAHRAGA DAN FISIOLOGI REPRODUKSI WANITA
}

\author{
Oleh: Eka Swasta Budayati \\ Jurusan Pendidikan Kesehatan dan Rekreasi FIK UNY
}

\begin{abstract}
Abstrak
Wanita memiliki keunikan fisiologis yang terletak pada tugas reproduksi yang diémbannya. Selain secara fisik, terdapat keunikan sosial dan emosianal yang sangat mempengaruhi pola fisiologis sistem reproduksi maupun pola perilakunya.

Secara garis besar semenjak pubertas, wanita mengalami menarche, menstruasi, kemungkinan kehamilan, klimakterium, menoupause dan senilium. Olahraga dan intensitas aktivitas fisik lain secara umum dapat mempengaruhi fisiologi reproduksi wanita.

Olahraga denagn intensitas sedang sangat dianjurkan untuk mendukung fisiologi reproduksi wanita, sedangkan olahraga dengan intensitas yang sangat tinggi serta aktivitas sedentary akan menghambat fisiologi reproduksi wanita.
\end{abstract}

Kata Kunci : wanita, reproduksi, olahraga

Banyak keunikan di dunia ini, namun yang paling unik adalah manusia dengan segala yang melekat padanya. Hal yang melekat tersebut diantaranya bentuk/kenampakan, sifat, tingkah laku dan hal-hal yang secara alami akan dialami/terjadi. Karena itu manusia mendapat julukan "bomo hominilupus, bomo-kreatur, homo ludens, homo sapien dan homo faber".

Seperti halnya dengan makhluk hidup yang lain, manusia juga terbagi menjadi jenis laki-laki dan wanita. Pada manusia, jenis wanita akan mengalami datang bulan, hamil, melahirkan dan menyusui. Pengalaman-pengalaman tersebut merupakan hal yang melekat, bukan hanya karena wanita ditandai oleh ciri-ciri tersebut, tapi juga diberi label baik secara emosional maupun sosial dengan hal tersebut.

Terdapat banyak hal yang mempengaruhi fisiologi reproduksi sepanjang perkembangan hidup wanita baik secara biologis maupun psikis. Aktivitas fisik merupakan salah satu hal diantaranya. Tulisan ini ingin mengulas pengaruh aktivitas fisik terhadap perkembangan reproduksi wanita. 


\section{TAHAPAN FISIOLOGI REPRODUKSI WANITA DAN PENGARUH OLAHRAGA}

\section{Menarche}

\section{a. Fisiologis Menarche}

Kekhususan sistem reproduksi wanita terjadi pada masa pubertas yang ditandai dengan timbulnya menarche. Menarche (datang bulan untuk pertama kalinya), sekitar usia 9-14 tahun, biasanya menyebabkan perlambatan pertumbuhan tinggi tapi meningkatkan pertumbuhan melebar. Setelah menarche, perempuan akan bertambah tinggi sekitar dua inchi. Terdapat penelitian yang menyimpulkan bahwa rata-rata pada 18 bulan setelah menarche terjadi percepatan pertumbuhannya sampai mencapai puncak. Walaupun demikian, hasil akhir pertumbuhan anak laki-laki lebih tinggi dibanding anak perempuan hingga dewasa. Wells (1985: 1617) menyatakan bahwa rata-rata wanita dewasa lebih pendek, lebih ringan dan lebih berlemak dibanding rata-rata pria dewasa. Pria dewasa mempunyai bahu lebih lebar, pinggul lebih ramping dan lingkar dada lebih luas dibanding ukuran relative tubuhnya. Perbedaan tersebut mulai muncul pada masa pubertas.

Kejadian yang diawali perempuan dalam masa pubertas ialah pertumbuhan badan yang cepat, timbulnya ciri-ciri kelamin sekunder, menarche dan perubahan psikhis. Apa yang menjadi penyebab utama menculnya masa pubertas belum diketahui, yang diketahui adalah bahwa ovarium mulai berfungsi di bawah pengaruh hormone gonadotropin dari hipofisis. Dalam ovarium, folikel mulai tumbuh, dan walaupun folikel-folikel tersebut tidak sampai menjadi matang karena sebelumnya mengalami atresia, namun folikel-folikel tersebut sudah sanggup mengeluarkan estrogen. Kira-kira pada waktu yang bersamaan, kelenjar korteks suprarenal mulai membentuk androgen, dan hormone ini memainkan peranan yang penting dalam pertumbuhan badan (Muzayyanah, 2002: 2). Semenjak timbulnya menarche, semakin timbul perbedaan fisik yang mendasar antara pria dan wanita. Wells (1985: 33) menyatakan bahwa wanita mempunyai volume darah, jantung, dan rongga dada lebih kecil, jaringan paru-paru lebih sedikit dan serabut otot yang lebih sedikit dan lebih kecil dibanding pria. Hal-hal tersebut menyebabkan perbedaan kinerja antara wanita dengan pria.

Tentu saja percepatan pertumbuhan tidak hanya akan mempengaruhi pertumbuhan skelet/rangka. Pertumbuhan otot, sejalan dengan perubahan jumlah dan distribusi lemak, akan mengubah komposisi tubuh orang dewasa. Paru-paru bertambah ukuran dan kapasitasnya, dan jantung menjadi dua kali lipat beratnya. Perut/lambung, ginjal dan volume darah mencapai ukuran dan tingkat keberfungsian orang dewasa pada masa percepatan pertumbuhan. Kekuatan dan daya tahan juga meningkat terutama pada anak laki-laki. Pada anak laki-laki juga terjadi peningkatan kemampuan untuk menetralisir sampah kimia yang dihasilkan oleh latihan (aktivitas fisik) seperti asam laktat yang menyebakan nyeri otot dan 
kelelahan. Dengan demikian sangat wajar bila anak perempuan lebih lemah dan lebih cepat lelah. Sebagian organ tubuh tidak mengalami percepatan pertumbuhan. Hingga awal masa remaja, tonsil dan adenoid, kelenjar limfa, dan masa limfa intestinum secara bertahap sudah meningkat ukurannya, setelah itu melambat dan berhenti tumbuh.

\section{b. Olahraga dan Menarche}

Pata atlet perempuan mengalami pengunduran memperoleh menarche. Orang yang sudah mulai aktif latihan sebelum mengalami menarche akan lebih lambat memperoleh menarche dibanding yang mulai aktif latihan setelahnya atau lebih lambat. Sementara Muzayyanah (2002: 3) menyimpulkan bahwa masa pubertas yang salah satunya ditandai dengan datang menarche merupakan masa pertumbuhan tercepat karena pengaruh hormone androgen. Sekilas ada hipotesa bahwa penundaan menarche memberi kemungkinan anak perempuan mempunyai kesempatan bertambah tinggi (karena masa pertumbuhannya bertambah panjang).

Alison \& Joane (1983: 395-396) menyatakan bahwa sinyal yang paling dramatis dan paling dapat dilihat saat awal masa remaja adalah percepatan pertumbuhan yang belum pernah terjadi sebelumnya dalam perkembangan individual sejak usia 2 tahun. Pertumbuhan tinggi terus berlangsung, sehingga anak laki-laki sudah mencapai $78 \%$ dan anak perempuan mencapai, $84 \%$ dari tinggi badan mereka saat dewasa. Meskipun pertumbuhan belum akan berhenti hingga usia sekitar 18 untuk anak perempuan dan 20 tahun untuk anak laki-laki, anak perempuan pada usia 14 tahun dan anak laki-laki usia 16 tahun, sudah akan mencapai $98 \%$ tinggi badan mereka saat dewasa.

\section{Olahraga dan Menstruasi}

\section{a. Fisiologi Menstruasi}

Menstruasi adalah proses pengeluaran darah dan cairan melalui kelamin wanita (vagina) yang mengandung sel-sel mati dari lapisan selaput lendir (lapisan endometrium) rahim (Depdikbud, 1997: 20). Haid dimulai pada pubertas sekitar 11-12 tahun sampai menopause pada sekitar 45-50 tahun (John Gibson, 2003: 341). Masa haid paling singkat (sedikit) adalah sehari semalam (24 jam) dan paling lama 15 hari. Walaupun demikian, pada umumnya wanita mengeluarkan darah haid selama 6 atau 7 hari. Interval siklus berkisar 21 sampai 35 hari dengan rata-rata siklus 28 hari. Menurut Derek Liewellyn-Jones (2002:13) haid adalah pengeluaran darah secara periodik, cairan jaringan dan debris sel-sel endometrium dari uterus dalam jumlah bervariasi.

\section{b. Olahraga dan Mentruasi}

Pada sebagian orang, menstruasi dapat menimbulkan masalah-masalah seperti kram/nyeri perut, mual, pusing/sakit kepala, nyeri pinggang, pegal-pegal 
pada tungkai, emosional dan timbul jerawat. Bila hal tersebut terjadi, maka olahraga (aktivitas fisik) akan menganggu. Maka dianjurkan untuk mengurangi atau mengganti dengan olahraga yang ringan, seperti jogging, jalan, dan tidak dianjurkan untuk pasif sama sekali bila kondisi tidak memaksa. Bagi wanita "normal" atau jika gangguan-gangguan tersebut tidak muncul, maka tidak ada anjuran untuk mengurangibbahkan menghentikan olahraga selama masa menstruasi.

Amenorchea adalah keadaan tidak datangnya menstruasi. Sebagian perempuan yang giat berolahraga dengan intensitas tinggi, kemungkinan dapat mengalami tidak menstruasi untuk satu siklus atau lebih. Penyebabnya dicurigai antara lain peningkatan kadar hormone androgen, penurunan fungsi ovari, hilangnya lemak tubuh, karena konsumen obat penunda menstruasi dan sebabsebab lain.

\section{Kehamilan}

\section{a. Fisiologi Kehamilan}

Kehamilan merupakan pengalaman yang unik disamping menarche dan menstruasi. Keunikan tersebut ada yang sangat dinikmati namun ada juga yang dianggap sebagai beban dengan berbagai alasan. Secara fisik, wanita hamil akan mengalami kesulitan fisik seiring dengan bertambahnya usia kandungan. Kehamilan akan meningkatkan berat badan. Pada akhir trimester pertama sebaiknya penambahan berat badan berkisar antara 1-2 kg, sementara berat janin sekitar 1 ons. Selanjutnya berat badan bertambah $0.5 \mathrm{~kg}$ per minggu. Akan tetapi banyak pula yang justru mengalami penurunan berat badan pada trimester pertama ini (Wells 1985: 173).

\section{b. Olahraga dan Kehamilan}

Kemampuan ambilan $\mathrm{O}_{2}$ wanita hamil tidak mengalami perubahan. Namun setiap beban latihan akan menaikkan ventilasi per menit, juga menurunkan kadar $\mathrm{O}_{2}$ antara arteri dan vena. Kehamilan meningkatkan frekuensi detak jantung per menit saat istirahat, sementara olahraga yang benar justru menurunkan. Meskipun demikian, dosis dan intensitas latihan sebaiknya diturunkan seiring bertambahnya usia kehamilan. Olahraga ringan menyebabkan glucagons, norepinefrin dan epinefrin. Dengan recovery 30 menit, tidak ada perubahan kadar glukosa dan cortisol. Meskipun belum ada kontraindikasi namun wanita hamil harus lebih berhati-hati dalam berolahraga. Jika terjadi ketidaknyamanan, flek atau pendarahan, nyeri, kelelahan atau tidak ada gerakan janin, maka aktivitas sebaiknya dihentikan.

\section{Klimakterium, Menoupause dan Senium}

\section{a. Fisiologi Klimakterium, Menoupause dan Senium}

Klimakterium merupakan masa peralihan antara masa reproduksi dan massa senium. David (1984: 54-56) menyatakan bahwa klimakterik adalah massa di 
mana wanita mengalami gejala penurunan fungsi ovari dan sekresi estrogen. Massa transisi dengan banyak perubahan. Klimakterik datang mendahului massa menopause. Shangold \& Mirkin (1988: 157) menyatakan bahwa secara fragmatis masa klimakterik dibagi menjadi 3, yaitu massa klimakterik awal (usia 35-45 tahun), peri menopause (usia 46-55 tahun) dan klimakterik akhir (usia 56-65 tahun).

Klimakterium bukan suatu keadaan patologis, melainkan suatu massa peralihan normal, yang berlangsung mulai beberapa tahun sebelum dan beberapa tahun sesudah menopause. Ada kesulitan untuk menentukan awal dan akhir masa klimakterium, namun secara umum dapat dikatakan bahwa klimakterium mulai kira-kira 6 tahun sebelum menopause berdasarkan keadaan endokrinologis (turunnya kadar estrogen dan naiknya kadar gonadotropin). Klimakterium berakhir kira-kira 6-7 tahun sesudah menopause. Pada saat tersebut, kadar estrogen sudah akan mencapai kadar yang rendah yang sesuai dengan kadar pada massa senium dan gejala-gejala neurovegetatif telah terhenti. Dengan demikian massa klimakterium berlangsung kurang lebih 13 tahun.

Menopause adalah menstruasi terakhir. Diagnosis menopause dibuat setelah terjadi amenorea sekurang-kurangnya satu tahun. Berhentinya menstruasi mungkin didahului pemanjangan siklus haid, dengan volume pendarahan yang semakin berkurang. Umur terjadinya menopause dipengaruhi oleh keturunan, kesehatan umum dan pola hidup yang didalamnya juga mencakup aktivitas fisik. Dewasa ini ada kecenderungan pengunduran usia menopause. Dengan kata lain, menopause datang pada usia yang lebih tua.

Kesimpulan sementara ada hubungan antara menarche dengan menopause. Makin dini seorang anak perempuan memperoleh menarche, maka akan makin lambat dia mengalami menopause, sebaliknya makin cepat menarche datang makin lambat menopause terjadi. Pada masa-masa sekarang, menarche datang makin dini, menopause makin lambat, sehinga masa reproduksi menjadi lebih panjang. Namun demikian datangnya menarche tidak mengalami perubahan keusia yang lebih muda lagi. Mungkin batas usia maksimal sudah tercapai.

Menopause merupakan proses alami. Jika menopause dianggap sebagai sesuatu yang negative, maka dapat menimbulkan perasaan bingung, sakit kepala, susah tidur, kemampuan konsentrasi turun, depresi fisik, energi fisik, dan mental turun, sama seperti menjelang menstruasi (Margareta, 1983: 58). Bagi yang berpikir positif, mereka menganggap bahwa menopause sebagai masa pembebasan diri, terutama dari kerepotan karena menstruasi, kerepotan dengan urusan $\mathrm{KB}$, termasuk kekuatiran akan hamil dan tambah anak.

Penurunan ovulasi merupakan akibat berkurangnya hormone pendukung (progesteron dan estrogen). Keadaan tersebut tidak hanya mempengaruhi organorgan reproduktif saja, tapi juga organ-organ yang lain. Pada massa itu, perempuan 
masih menghasilkan estrogen dari ovarinya dan juga dari adrenal hingga 10 - 15 tahun setelah berhentinya menstruasi, meskipun dalam jumlah yang kecil.

Peningkatan kadar estrogen, yang berlawanan dengan estradisol, yang merupakan estrogen penting dalam usia produktif, pada masa menopausal dan massa apost-menopausal meningkatkan insiden kanker payudara dan kanker uterin. Penurunan kadar estrogen menyebabkan penurunan kemampuan reproduksi, perubahan pola produksi hormone adrenal yang sangat berguna untuk penguraian protein. Estrogen sangat dibutuhkan dalam pembentukan protein, hanya lebih lemah pengaruhnya.

Akibat penguraian protein, maka terjadi penurunan kualitas jaringan, seperti tulang, otot, kulit, rambut, dan kuku secara bertahap. Juga terjadi penurunan aktivitas osteoblast, sehingga matriks tulang mengalami penurunan kualitas dan terjadi penurunan proses penulangan. Selanjutnya akan meningkatkan resiko osteoporosis dan fraktur. Kondisi tersebut merupakan proses aging. Elemenelemen yang perlu dipehatikan dalam aging adalah: (1) Proses aging berlangsung sepanjang hayat, tetapi akan nampak lebih nyata pada masa post-menopause, (2) Aging menurunkan kapasitas fungsional sel, organ, dan makhluk secara keseluruhan, (3) Aging menyebabkan penurunan elemen struktural.dalam tubuh, (4) Aging menurunkan efektivitas respon terhadap faktor-faktor internal dan eksternal, (5) Aging meningkatkan kemungkinan terparah akibat dis-fungsi, yaitu kematian (David, 1984: 4).

Senium merupakan massa tercapainya keseimbangan baru, sehingga tidak ada lagi gangguan vegatatif maupun psikhis, yang mencolok pada massa ini ialah kemunduran fungsi organ-organ tubuh dan kemampuan fisik sebagai proses tumbuh kembang menjadi tua (aging). Pada masa senium ini terjadi proses osteoporosis yang makin cepat. Walaupun penyebabnya belum jelas betul, namun berkurangnya jumlah dan pengaruh hormone steroid dan berkurangnya aktivitas osteoblast memainkan peranan yang sangat penting. Sekilas nampak bahwa setelah menopause, perempuan menjadi semakin lemah. Karena penurunan fungsi organ, termasuk syaraf, maka perempuan akan menjadi pikun, otot dan jaringan ikatnya tidak lagi lentur, serta menyebabkan menurunnya fungsi panca indera. Proses tersebut tidak dapat dihindari, akan tetapi dapat diperlambat, sehinga perempuan dapat menikmati masa tuanya dengan tetap aktif. Sekali lagi usaha yang dapat dilakukan untuk memperlambat proses penuaan adalah dengan mengatur pola makan dan pola hidup sehat. Pola makan meliputi mengurangi konsumsi lemak dan gula. Perbanyak asupan sayur, buah dan air putih. Pola hidup mencakup berpikiran positif, tetap aktif dalam berbagai kegiatan sosial dan tentu saja tetap aktif berolahraga. 


\section{b. Olahraga Pada Klimakterium, Monopause dan Senium}

Aging merupakan serangkaian proses yang tidak mungkin dihindari. Namun ada beberapa langkah yang dapat kita tempuh untuk sekedar mengurangi percepatan proses aging. Olahraga merupakan hal yang dapat menunda penuaan dini. Olahraga akan merangsang seluruh sistem yang ada di dalam tubuh untuk berfungsi dengan lebih baik. Sifat olahraga yang cocok adalah olahraga aerobik dengan intensitas sedang. Olahraga berperan sebagai penjaga dan peningkat kebugaran jasmani. Olahraga juga beperan sebagai perangsang diproduksinya marfin tubuh, yaitu endorphin. Endorphin ini akan memberi rasa segar, nyaman dan gembira. Dengan demikian juga akan mengurangi stress dan kekacauan yang disebabkan oleh perubahan hormonal. Hanya sayangnya, wanita cenderung memilih hal-hal yang atraktif, kurang memperhatikan apa yang mestinya diperhatikan dan emosional, sehingga sering tidak memperoleh hasil optimal dari olahraga yang dilakukannya, seperti apa yang disampaikan oleh (Davidson \& Murphy, 1986: 273-278).

Olahraga dan aging meningkatkan stress oksidatif terhadap tubuh. Secara alami, tubuh sudah dilengkapi dengan enzyme antioksidan. Enzyme antioksidan tersebut di dalam organ-organ vital, seperti hati dan jantung mengalami penurunan bersamaan dengan proses aging. Di dalam sistem tertentu, seperti mitokondria atau jalur metabolisme, enzyme tersebut dapat beradaptasi. Pada saat melakukan latihan berat, stress oksidatif dan asupan oksigen meningkat, sementara kemampuan menghasilkan antioksidan menurun (Ji, 1993: 230). Pernyataan Ji tersebut didukung oleh Alessio (1993: 218) yang menyatakan bahwa jika latihan menyebabkan kenaikan asupan oksigen per menit sebesar $10-15$ fold dibanding saat istirahat, maka metabolisme dan stress oksidatif akan naik, selanjutnya akan menaikkan radikal bebas. Untuk itu disarankan agar orang yang terlatih tetap melakukan latihan dengan intensitas sedang.

\section{KESIMPULAN}

Wanita mengalami tahap perkembangan reproduksi berupa menarche, menstruasi, kehamilan, klimakterium, menopause dan senilium. Olahraga berpotensi untuk mempengaruhi fungsi fisiologis tersebut. Olahraga dan aktivitas fisik lain secara umum dapat mempengaruhi fisiologi reproduksi wanita. Olahraga dengan intensitas sedang sangat dianjurkan untuk mendukung fisiologi reproduksi wanita, sedangkan olahraga dengan intensitas yang sangat tinggi serta aktivitas sedentary akan menghambat fisiologi reproduksi wanita. 


\section{DAFTAR PUSTAKA}

Alessio, H. M., (1993). Exercise-induce Oxidative Stress. Medicine and Science in Sports and Exercise, Vol 25, No. 2, p.p.218-228.

David, H. A, (1984). The Biomedical Basis of Gerontology; John Wright PSG. Inc., 545 Great Road, Littleton, Massachussetts 01460, USA.

Ji, L., L., (1993). Antioksidant respon to exhaustic and aging, Medicine Science in Sports and Exercise. Vol. 25, No. 2: 225 231.,

Margarete, S., (1981). Women, Health and Choice: Prentice Hall, Inc., Englowood Cliffs, N. J. 07632.

Shangold Mona, M. and Mirkin Gabe, (1988). Women and Exercise: Pbysiology and Sports Medicine, F. A. David Company, United States of Amerika.

The 1984 Olympic Scientific Congress Proceedings Vol. 5: 1986: Sport and Aging, Human Kinetik Publishing, Inc. Champaign Illinois.

Wells Christine, L., (1985). Medicine and Science in Sports and Exercise. the Amerikan College of Sport Kinetics Publisher, Inc. Box 5076, Compaign, IL 61820.

Alison Clarke - Stewart and Joanne Barbara Koch, (1983). Cbildren Development Through Adolescence. John and Wiley \& Sons, Inc, USA.

Joan Vickers, Michaell, and Terry T: (1980). Research Quarterly for Exercise and Sport. Vol. 51 No 2.pp.407-416, American Alliance for Health, Physical Education, Recreation and Dance. ISSN 0270-1367.

Muzayyah, (2002). Periodesasi Kebidupan Perempuan: Presentasi Ilmiah. 